\title{
THE WINE TOURISM OF HUNGARY FROM THE POINT OF FESTIVALS
}

\author{
Géza Szabó \\ Bence Závodi ${ }^{1}$
}

\begin{abstract}
In today's tourism festival tourism which organized around various events play a significant role. The themes of these events move on a wide scale, thanks to this the supply of destinations, which build upon festival tourism, is complex and colourful. The central element of the wine gastronomy festivals is the wine, which is complemented by different services. These services and the programmes define the type of the wine and gastronomy related festivals. We determined four categories: wine festival, wine gastronomy, wine culture and harvest festival, which illustrate how these events want to satisfy the need of the guests. In the categories we can find numerous differences regarding the length, the turnover and the scope of the events. The primary aim of this research is the introduction and the tourism geographical analysis of the Hungarian wine gastronomy festival supply in 2017. During the research we had collected the Hungarian wine gastronomy festivals from different sources then, with the help of the compiled database, we defined the geographical characteristics of the supply. Thanks to our results we located the wine gastronomy centres of Hungary, which comparison with the reputation of wine producing areas among consumers could lead to additional interesting results. The proportion of the defined categories demonstrates well the trends of consumers. The distribution of festivals during the year is also the result of certain habits of the consumers.
\end{abstract}

Keywords: wine, gastronomy, wine tourism, festival tourism, Hungary

\section{INTRODUCTION}

The vineyards of Hungary made a total of 62 thousand hectares in 2014, which, in comparison with the total of the vine growing areas of the world (7,541 thousand hectares), is less than $1 \%$. As regards the quantity of wine produced in Hungary, it was 2.6 million hectolitres in the same year, which is almost $1 \%$ of the world's total production (270 million hectolitres) (Österreich Wein 2018). These data do not suggest that Hungarian wines and wine producing areas are significant, although several of our 22 wine producing areas (e.g. Tokaj, Villány, Eger, Badacsony) are recognised especially by the European consumers. In the improvement of the

\footnotetext{
${ }^{1}$ MSc, University of Pécs - Institution of Geography and Earth Sciences, bence.zavodi@gmail.com
} 
recognition of the Hungarian wines, in addition to excellent quality, wine-related festivals increasing the touristic attraction and fame of the wine producing areas play a role.

Interest in festivals has increased in recent decades, as a result of which festival tourism has become one of the dominant segments of today's tourism sector. Festivals can have several positive impacts on their destinations, including the preservation of the culture of the local inhabitants (Getz, 2008). By the intensification of the cultural life of a festival venue, besides the external image the attachment of the inhabitants to their own settlement also strengthens (Leenders, 2010). By the increased touristic attractivity, the level of satisfaction of guests arriving at the destination also increases, as a result of which the settlement becomes more attractive to tourists (Grappi \& Montanari, 2011).

A special category of festivals is events related to wine, enological tourism and wine gastronomy. Enological tourism is a very complex tourism product, in the opinion of Getz (2000) it can be approached from three aspects: from the side of wine producers, destinations and tourists. According to Hall et al. (2000), enological tourism is not only about visiting vineyards and wineries but also about participation in different wine-related events and exhibitions. Wine-related festivals and events play an important role in the enological tourism of the respective destinations, closely attached to the culture and traditions of the given region (Várhelyi, 2012). Hungary has long traditions in viticulture and wine production, and wine producing areas and settlements celebrate their related holidays in accordance with their traditions (Várhelyi, 2016). In Germany, a country very rich in traditions of enological tourism, the role of wine festivals is seen in their potential of gaining new target groups (Rüdiger et al. 2015). Rück (2013) defined several advantages of wine festivals which may be utilised by the wineries, e.g. by the direct sales of their high prestige products. For the destination management organisation of the respective region it may entail the increase of the volume of guests, the improvement of the recognition and the strengthening of the positive image. Even local inhabitants can feel the positive impacts by the increased attractivity of their place of residence.

Learning the gastronomy of the respective regions has been appreciated in recent years. Getting to know the cuisine and/or wines of some regions has become a primary motivation by now in many cases (López-Guzmán et al. 2012). In the view of Garibaldi et al. (2017) tourists participating in enological tourism are interested in large numbers not only in alcoholic beverages but also in foods. It supports the concept that foods and drinks together, closely integrated and supplementing each other, are important parts of tourism. In the themes of gastronomy festivals, the preparation of dishes, their introduction and tasting play a central role. They can be 
organised not only around food but also beverages (wine, beer, pálinka). One type in this category is wine gastronomy festivals whose central element is wine, supplemented by various services. Szabó (2017) says that wine gastronomy festivals can be classified into four categories:

- Wine festival: Basically the local, regional and national exhibitions for the wines of the wine regions for the public with a significant wine professional content.

- Wine gastronomy: A gastronomy event, festival where the foods and drinks are both presented to the audience.

- Wine culture: The meeting of the wine and the arts, a cultural event, festival where the wines also play a highlighted role in the programme.

- Harvest festival: Harvest folk feasts, festivals, balls, where the audience meets the wine culture and the traditions of the wine region with particular concern.

Hungary has significant traditions in viticulture and wine production, which is proved by the number of wine related events that is growing year after year. The Hungarian vineyards make a total of 22 wine producing areas (Figure 1), with a total territory of approximately 62 thousand hectares.

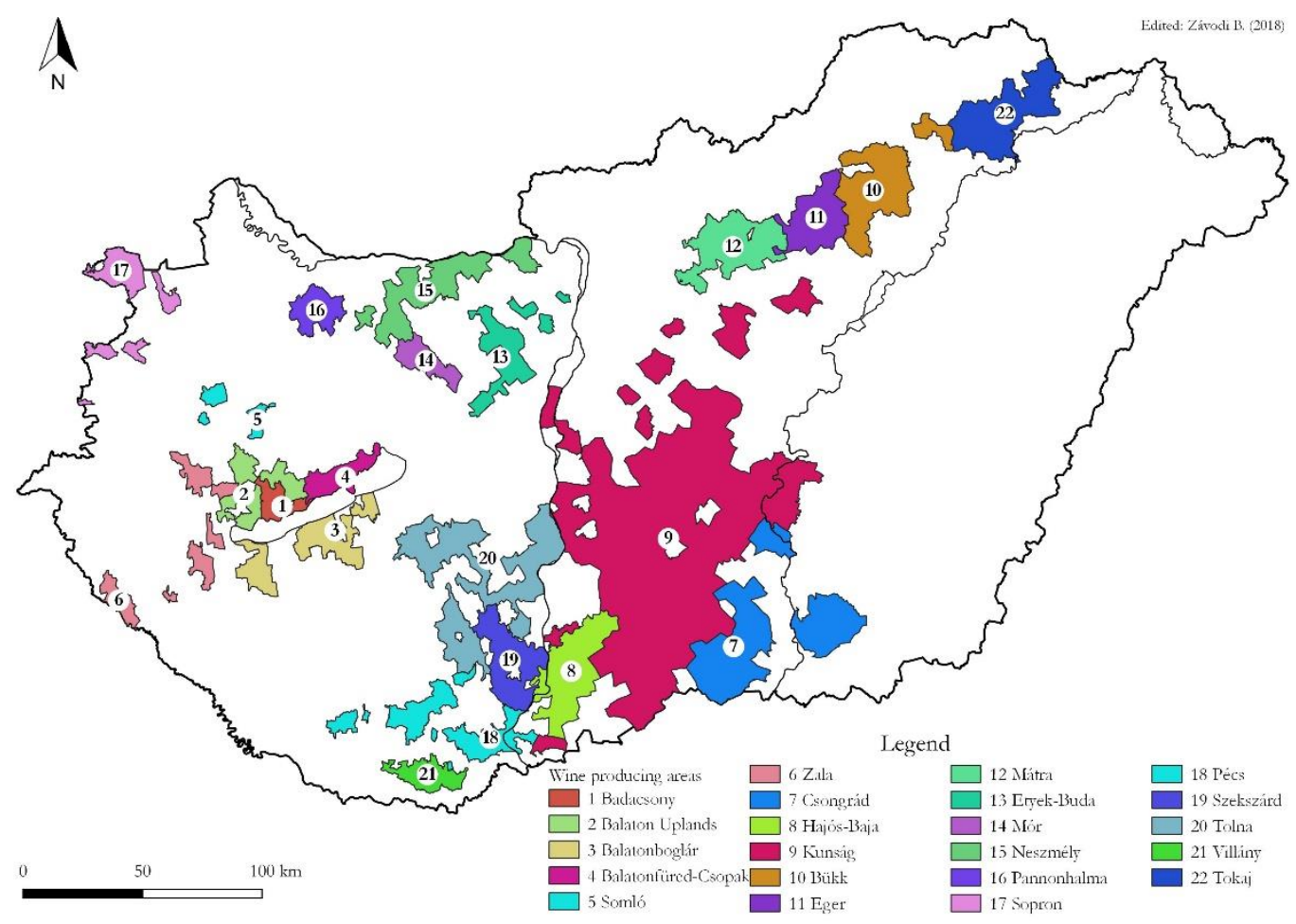


Fig. 1: Wine producing areas of Hungary

Source: own editing

\begin{abstract}
AIMS
The main objective of the research was the exploration of the characteristic features of the supply of wine gastronomy festivals in 2017 in Hungary. This requires the investigation of the issue from several aspects, such as the categorisation of festivals and the proportion of the respective categories from the total of the supply. Furthermore, the survey of the territorial characteristics of such events is necessary, on the basis of which their tourism geographical features can be defined.
\end{abstract}

\title{
METHODS
}

Using different sources, we collected the wine gastronomy festivals in Hungary. Festivals and information concerning them were collected from the websites of wine producing areas and wine routes, their web 2.0 pages and the websites of programme guides with national recognition. These events were analysed on the basis of their supply, and then classified into the categories indicated above, on the basis of the assessment of their themes and programmes (Szabó - Szeidl - Závodi 2017). Using the database compiled, we determined the primary, especially geographical features of the supply.

\section{RESULTS}

\section{SUPPLY OF WINE GASTRONOMY FESTIVALS IN HUNGARY}

Enological tourism is popular in Hungary, which is well demonstrated by the fact that no less than 247 wine gastronomy festivals were organised in Hungary in 2017. The preliminarily defined four categories had different proportions (Figure 2) from the total of the supply. Wine festivals have a significant enological professional 
content, targeting a much narrower layer of visitors. Accordingly, their number is the lowest of all four categories, not more than 38 such festivals were held in Hungary in 2017. The number of harvest festivals, 41, is not much above that of the wine festivals. The number of these festivals is primarily due to the fact that the date of their organisation is closely connected to harvesting time (from late August to early October). Despite this small number, they have an outstanding role in the preservation and transition of traditions related to the wine producing areas and the harvest. Hungary has several traditions related to wine gastronomy. Wines and foods, supplementing each other, are dominant parts of the supply of the festivals. Thank to the several traditions connected to wines and foods, one-third of all thematic festivals of wine (71) are in the category of wine gastronomy. The broadest category is wine culture, as almost $40 \%$ of all events ( 97 festivals) were listed here. One reason for this is the diverse supply of these events; they are capable of moving masses of people, especially with their music and arts content. They contain elements that are interesting for several target groups. This category contains several festivals with long tradition and national range of attraction.

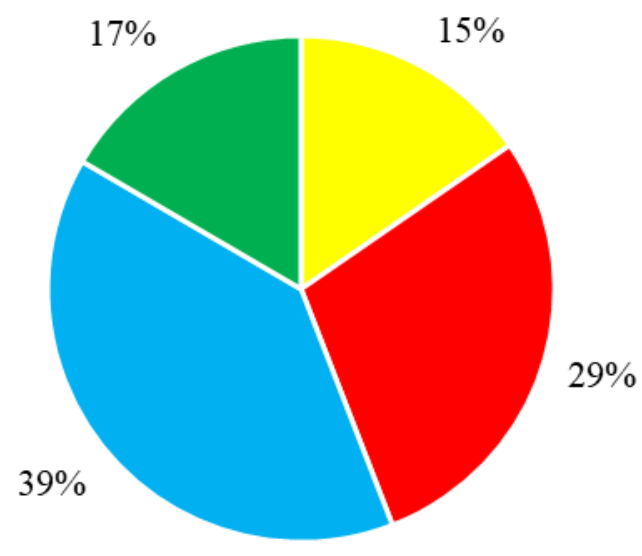

Wine festival $\backsim$ Wine gastronomy $\backsim$ Wine culture $\square$ Harvest festivals

Fig. 2: Proportion of wine gastronomy festival categories (Hungary 2017)

Source: based on online sources own editing

Wine gastronomy festivals are typically organised in territories defined as wine producing areas of Hungary (Figure 3), but there are many exceptions as well, settlements that are not situated in wine producing areas. In 2017 a total of 247 wine gastronomy festivals were organised in Hungary, one-third of them $(31 \%)$ in 
settlements outside wine producing areas. The main reason why these settlements organise wine gastronomy festivals is to use the potential lying in festivals, which may also play an important role in the shaping of the external image and fame of the destination. A significant part of these settlements are active tourism destinations anyway, and so the values lying in Hungarian wines are also offered for the increase of the attraction of their events. Another part of them, as big cities, are significant consumer markets where the demand of the local consumption is satisfied.

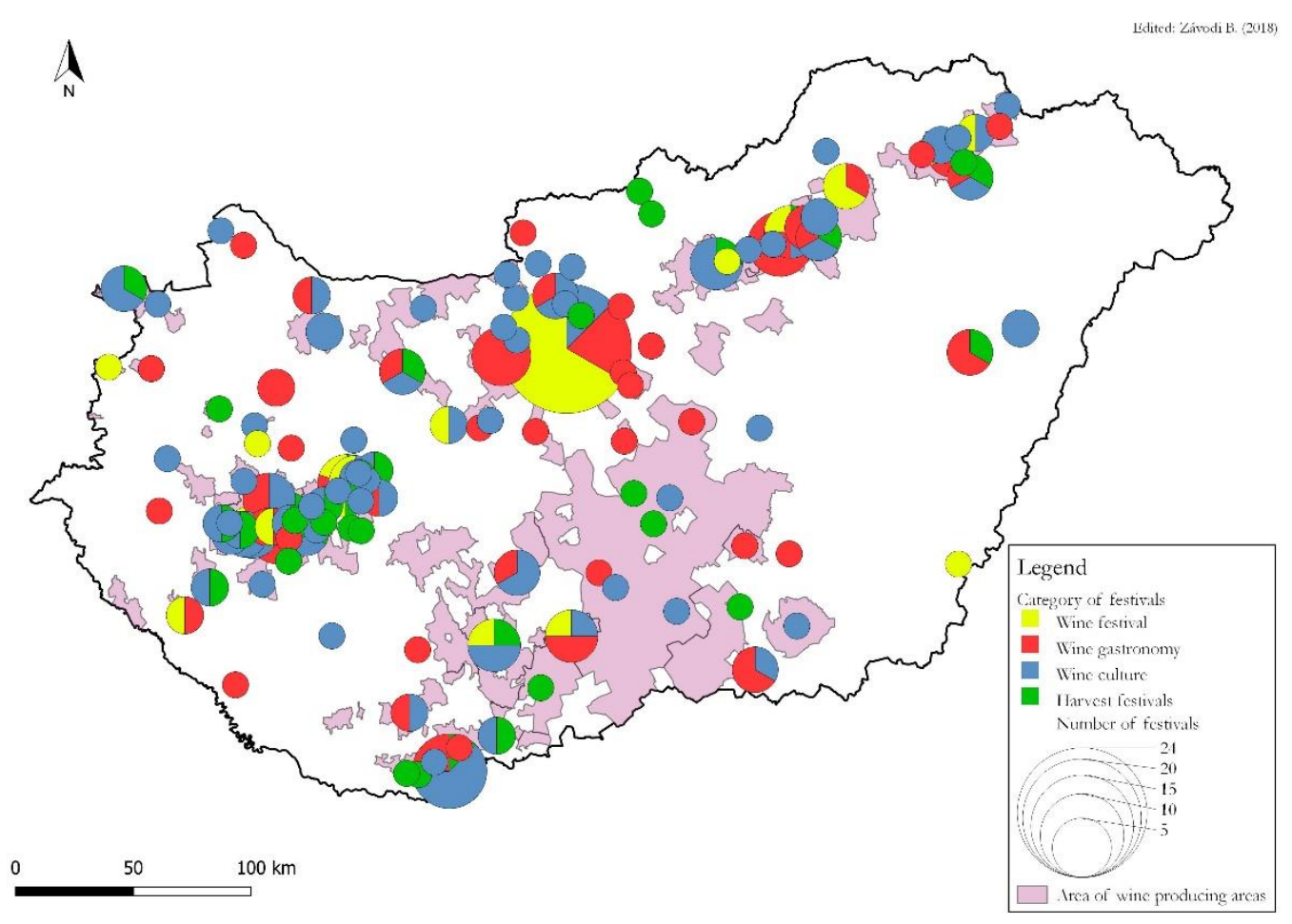

Fig. 3: Spatial distribution of wine gastronomy festivals (Hungary 2017)

Source: based on online sources own editing

Wine festivals are usually connected to the famous wine producing areas of Hungary, like for example Tokaj, Villány and Eger. A considerable part of the events in the wine festival category is organised in the capital city of Hungary, Budapest. The city, coming from its size, has a significant consumer market that guarantees the demand for and the success of such events. The regional distribution of wine gastronomy festivals is more even. The main junction is Budapest and its surroundings, but we also have to mention Etyek as a wine gastronomy centre of Hungary. The wine culture festivals are typically concentrated in the territories of 
the wine producing areas, but the role of wine cities is also determining, see e.g. Sopron, Villány, Eger and Pécs. Harvest festivals too are primarily linked to wine producing areas, but in this category too we find settlements (Ópusztaszer, Szécsény) that have no enological traditions, still they organise such festivals every year.

\section{WINE GASTRONOMY FESTIVALS IN HUNGARY'S WINE PRODUCING AREAS}

Hungary has 22 wine producing areas that organised various numbers of wine gastronomy festivals in 2017 (Figure 4). Eight wine producing areas organised at least ten or more wine gastronomy festivals. These are the wine producing areas that make the best use of the potential lying in wine gastronomy festivals, like generating turnover, increasing the fame of the wine producing area and the preservation of traditions. The most popular category in most of the wine producing areas was wine culture. These festivals are for a broader audience and the large-scale open-air wine weeks, whose number is dominant in Hungary, are also in this category. The number of festivals in the wine gastronomy group is the highest in proportion in the following wine producing areas: Eger, Etyek-Buda and Kunság. The Eger wine producing area has several traditions related to foods that are well harmonised with the wines of the area. The Etyek-Buda wine producing area is a wine gastronomy centre of Hungary, proved by the fact that the so-called "Etyek Picnic" is now organised for times a year, due the great success. 


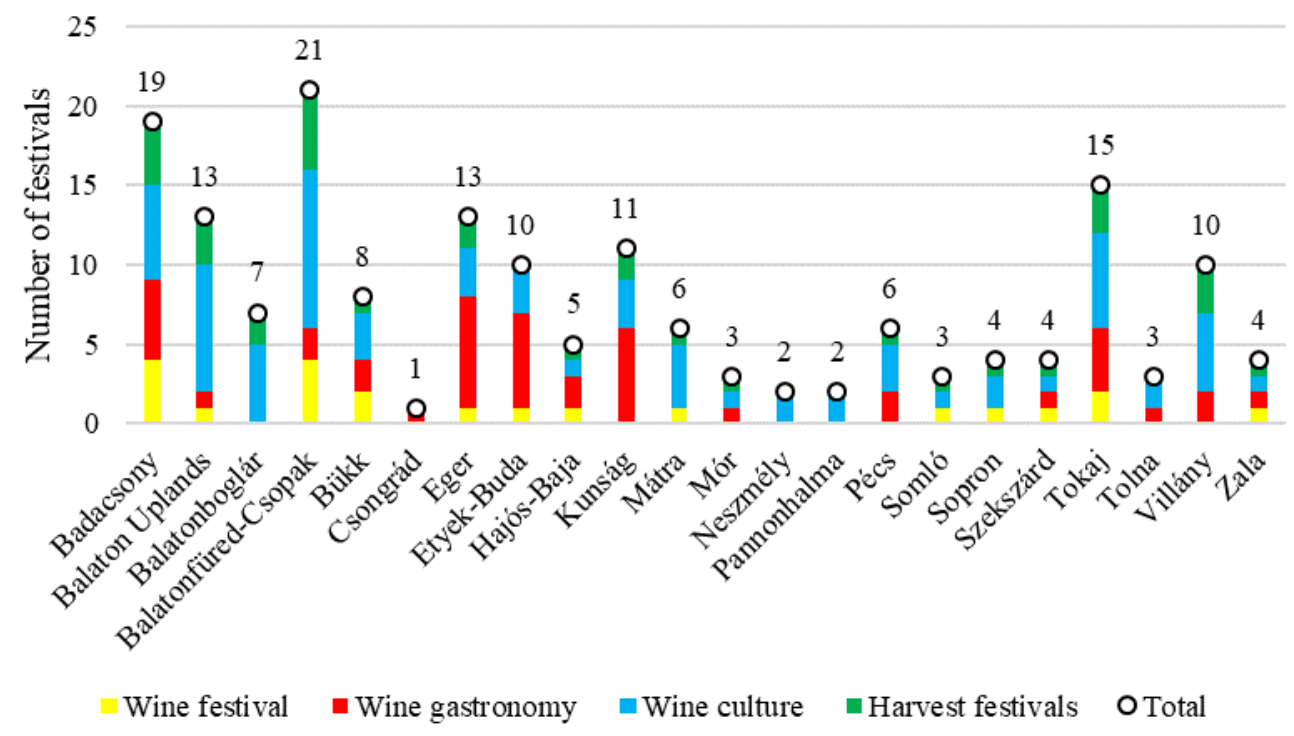

Fig. 4: Distribution of wine gastronomy festivals among wine producing areas (Hungary 2017)

Source: own editing based on online sources

Harvest festivals could be found in the supply of all wine producing areas, except for five. This demonstrates that almost all Hungarian wine producing areas find it important to preserve the traditions, especially the cherishing of harvest traditions. The number of wine festivals varied across the wine producing areas: this type is missing from the supply of some less recognised and lower-prestige wine producing areas, but even some well-known and high-prestige wine producing areas neglect the organisation of wine festivals.

\section{SUMMARY}

In recent years, following the consumer trends, interests in wine and gastronomy has increased, which is proved by the increase in the number of wine gastronomy festivals organised in Hungary: it grew from 151 in 2012 to 223 by 2016. One reason for this is that more and more festival organisers see, as a result of the increased interest, a potential in festivals connected to wine and gastronomy. The other reason might be that more and more festival organisers, wine producing areas and wine routes see it important to do marketing on online platforms, following current trends. 
As a consequence, a growing number of festivals appear on the examined websites year after year.

Wine gastronomy festivals are usually linked to the wine producing areas of Hungary, but several settlements organise such events as well that do not belong to any wine producing area. In these settlements it is primarily the size of the consumer market and the volume of tourism that are influencing factors.

The most popular category was the extremely diverse and complex wine-culture, with almost $40 \%$ of all events in this category. These festivals, with their colourful programmes, aim at several target groups, which is a guarantee of their success in many cases. In the supply of the wine producing areas too this was the dominant category, which is in line with the present phenomenon of growing consumer expectations in tourism, and so the wine producing areas and wine routes also try to satisfy these demands at the highest possible level.

\section{ACKNOWLEDGEMENTS}

This publication/research has been supported by the European Union and Hungary and co-financed by the European Social Fund through the project EFOP-3.6.2-162017-00017, titled "Sustainable, intelligent and inclusive regional and city models".

\section{REFERENCES}

Garibaldi, R., Stone, M., Wolf, E. and Pozzi, A. (2017). Wine travel in the United States: A profile of wine travellers and wine tours. Tourism Management Perspectives, 23, pp.53-57.

Getz, D. (2000). Explore wine tourism. New York: Cognizant Communication.

Getz, D. (2008). Event tourism: Definition, evolution, and research. Tourism Management, 29(3), pp.403-428.

Grappi, S. and Montanari, F. (2011). The role of social identification and hedonism in affecting tourist re-patronizing behaviours: The case of an Italian festival. Tourism Management, 32(5), pp.1128-1140.

Hall, C. M., Sharples, L., Cambourne, B., Macionis, N. (2000): Wine tourism around the world: Development, management and markets. London: Elsevier.

Leenders, M. (2010). The relative importance of the brand of music festivals: a customer equity perspective. Journal of Strategic Marketing, 18(4), pp.291-301. 
López-Guzmán, T., Rodríguez-García, J., \& Vieira-Rodríguez, A. (2012). Análisis diferenciado del perfil y de la motivación del turista nacional y extranjero en laruta del vino del Marco de Jerez. Gran Tour: Revista de Investigación Turística, 6, pp.83-100.

Österreich Wine. (2018).Der Weltweinmarkt. [online] Available at: https://www.oesterreichwein.at/presse-multimedia/statistik/ [Accessed 25 Oct. 2018].

Rück, H. (2013): Erfolgskontrolle von Weinfesten. In: Scherhag, K. hrsg. Weintourismus und Marketing. Lohmar-Köln, pp. 11-32.

Rüdiger, J., H. Hanf, J., Schweicker, E. (2015): Die Erwartungshaltung von Weintouristen in Deutschland. Berichte über Landwirtschaft, Zeitschrift für Agrarpolitik und Landwirtschaft. 93(2), pp.1-23.

Szabó, G., Szeidl, K., Závodi, B. (2017): Tradition and Innovation in the Festival Tourism of South Transdanubia. In: Hrvojević, M. P., ed., 17th Contemporary Trends in Tourism and Hospitality: NEW SPACES IN CULTURAL TOURISM, University of Novi Sad, Department of Geography, Tourism and Hotel Management, pp. 1-9.

Várhelyi, T. (2012): A borturizmus. Főiskolai jegyzet, EKF Líceum Kiadó.

Várhelyi, T. (2016): A borfesztiválok szerepe és Eger innovatív fesztiváljai. In: Jászberényi, M., Zátori, A., Ásványi, K. ed., Fesztiválturizmus. Akadémiai Kiadó, pp. 220-226. 